\title{
OPTIMASI KOMUNIKASI PADA MASA KEBIJAKAN WORK FROM HOME (WFH) MENGGUNAKAN APLIKASI ZOOM BAGI SISWA PKBM BHAKTI ASIH CILEDUG
}

\author{
1) Painem, ${ }^{2)}$ Hari Soetanto \\ ${ }^{1,2)}$ Program Studi Teknik Informatika, Fakultas Teknologi Informasi, Universitas Budi Luhur \\ 1,2)Jl. Ciledug Raya, Petukangan Utara, Jakarta Selatan, DKI Jakarta, Indonesia \\ E-mail: ${ }^{1)}$ painem@budiluhur.ac.id, ${ }^{2}$ hari.soetanto@budiluhur.ac.id
}

\begin{abstract}
ABSTRAK
Salah satu kebijakan Pemerintah Indonesia untuk mencegah penyebaran Covid-19 adalah kebijakan bekerja dari rumah atau work from home (WFH) bagi sebagian besar institusi dan perusahaan. Dengan pengurangan aktivitas fisik, interaksi dalam pekerjaan maupun komunikasi dengan berbagai pihak harus memanfaatkan teknologi termasuk telepon, surat elektronik, pesan singkat, dan panggilan video. Sebagai lembaga pendidikan non formal, PKBM Bhakti Asih memiliki siswa yang sebagian besar telah bekerja di berbagai bidang pekerjaan. Salah satu permasalahan pada PKBM Bhakti Asih terkait pola komunikasi jarak jauh adalah literasi teknologi yang tidak merata bagi seluruh siswa. Kurangnya sosialisasi dan pelatihan untuk meningkatkan literasi teknologi menyebabkan kesulitan bagi siswa jika ingin berkomunikasi secara interaktif dengan banyak pihak, baik dalam pekerjaan maupun belajar-mengajar. Hal tersebut yang menjadi latar belakang penyelenggaraan kegiatan pengabdian kepada masyarakat ini. Tujuan utama dari kegiatan ini adalah meningkatkan literasi teknologi bagi siswa PKBM Bhakti Asih dalam menggunakan aplikasi Zoom Cloud Meeting sebagai salah satu sarana komunikasi video massal. Peserta kegiatan ini melibatkan siswa dan guru di PKBM Bhakti Asih. Selain bermanfaat dalam memperlancar kegiatan belajar-mengajar, bagi siswa tentunya pelatihan ini akan bermanfaat dalam pekerjaan di perusahaannya masing-masing.
\end{abstract}

Kata Kunci: komunikasi video, literasi teknologi, pandemi covid-19, pusat kegiatan belajar masyarakat

\begin{abstract}
One of the policies of the Indonesian Government in preventing the spread of Covid-19 is the work from home (WFH) policy for most institutions and companies. With the reduction of physical activity, interactions at work and communication with various parties must take advantage of technology including telephone, electronic mail, instant messages, and video calls. As a non-formal education institution, PKBM Bhakti Asih has students, most of whom have worked in various fields of work. One of the problems in PKBM Bhakti Asih related to long-distance communication patterns is the unequal technological literacy for all students. Lack of socialization and training to improve technological literacy causes difficulties for students to communicate interactively with many parties, both in work and in teaching and learning. This is the background for the implementation of this community service activity. The main objective of this activity is to improve technological literacy for PKBM Bhakti Asih students in using the Zoom Cloud Meeting application as a means of mass video communication. Participants in this activity involved students and teachers at PKBM Bhakti Asih. Apart from being useful in facilitating teaching and learning activities, for students, of course, this training will be useful in working in their respective companies.
\end{abstract}

Keyword: video communication, technological literacy, covid-19 pandemic, community-based learning centers

\section{PENDAHULUAN}

Pusat Kegiatan Belajar Masyarakat (PKBM) merupakan salah satu satuan pendidikan nonformal yang menyediakan layanan dan kegiatan pembelajaran bagi warga masyarakat agar lebih berkompeten dan lebih produktif. Satuan pendidikan PKBM dikelola secara mandiri oleh masyarakat, atau dengan kata lain dimiliki, dikelola dan untuk masyarakat. Secara umum, PKBM memiliki posisi penting dalam penerapan pendidikan nonformal atau pendidikan luar sekolah. Menurut Undang-undang No. 20 Tahun 2003 tentang Sistem Pendidikan Nasional, PKBM dinyatakan sebagai salah satu satuan pendidikan nonformal. PKBM Bhakti Asih beralamat di Jl. Raden Fatah RT.003/10 No. 7, Kec. Ciledug, Kota Tangerang, Banten. Siswa yang belajar di PKBM Bhakti Asih sebagian besar adalah masyarakat yang bekerja di berbagai sektor pekerjaan, baik sektor formal maupun non formal. 
Kebijakan "work from home" (WFH) dari pemerintah yang bertujuan untuk mencegah penularan virus Corona (Covid-19) saat ini membuat banyak istansi mencari sarana untuk melakukan komunikasi dan koordinasi jarak jauh. Sebagai salah satu institusi pendidikan nonformal, PKBM Bhakti Asih juga menerapkan kebijakan bekerja dari rumah bagi guru, staf dan pengeloa PKBM. Saat ini komunikasi dan koordinasi antara kepala sekolah, guru dan staf dilakukan melalui aplikasi Whatsapp. Namun kelemahan aplikasi Whatsapp adalah saat diperlukan komunikasi langsung yang interaktif dengan banyak peserta. Fasilitas panggilan video pada Whatsapp terbatas hanya untuk 4 (empat) orang.

Sementara itu, siswa PKBM Bhakti Asih yang sebagian besar telah bekerja di berbagai sektor pekerjaan juga mengalami kesulitan berkomunikasi massal akibat kebijakan pembatasan interaksi fisik. Komunikasi diperlukan baik dalam proses belajar-mengajar di PKBM Bhakti Asih maupun dalam pekerjaan masing-masing siswa. Literasi teknologi bagi siswa juga dirasakan belum merata. Tidak semua siswa sudah terbiasa berkomunikasi melalui aplikasi panggilan video seperti Zoom Cloud Meeting atau Google Meet. Berdasarkan latar belakang tersebut, maka kegiatan pengabdian pada masyarakat (abdimas) ini penting dilakukan dalam rangka mengoptimasi komunikasi dan koordinasi jarak jauh bagi siswa maupun guru PKBM Bhakti Asih.

Kegiatan peningkatan literasi teknologi yang dilaksanakan pada sebuah pusat kegiatan belajar masyarakat di berbagai wilayah sudah banyak dilakukan dengan berbagai tujuan. Beberapa kegiatan peningkatan literasi teknologi tersebut antara lain dilakukan dalam bentuk pelatihan Microsoft Word pada PKBM Bhakti Asih [1], pelatihan komputer di PKBM Bina Terampil Mandiri Kertawangi [2], pelatihan manajemen acara pada PKBM Ristek Nusantara Jaya [3], pelatihan pengetahuan bisnis dan aplikasi komputer pada PKBM Kelurahan Gayam [4], pendampingan bisnis [5], dan pelatihan pembuatan karya tulis bagi PKBM Kelurahan Kertosari Ponorogo[6].

Berdasarkan hasil identifikasi kebutuhan mitra PKBM Bhakti Asih yang dilakukan melalui proses wawancara dan observasi baik secara langsung maupun tidak langsung, maka permasalahan mitra secara khusus sebagai berikut :

1. Literasi teknologi yang masih kurang dan belum merata bagi guru dan staf mitra, khususnya dalam penggunakan teknologi komunikasi video massal

2. Literasi teknologi yang masih kurang dan belum merata bagi siswa PKBM Bhakti Asih, khususnya dalam penggunakan teknologi komunikasi video massal dalam rangka mendukung proses belajar mengajar dan komunikasi di instansi tempatnya bekerja.

3. Kebijakan pembatasan interaksi fisik mengakibatkan koordinasi dan komunikasi antara kepala sekolah, guru, staf, dan siswa PKBM menjadi terhambat.

\section{METODE PELAKSANAAN}

Gambar 1 menunjukkan metode atau tahapan pelaksanaan kegiatan pengabdian kepada masyarakat di PKBM Bhakti Asih. Tahapan tersebut menjadi acuan dan pedoman agar kegiatan berjalan dengan baik, terencana dan terstruktur. 


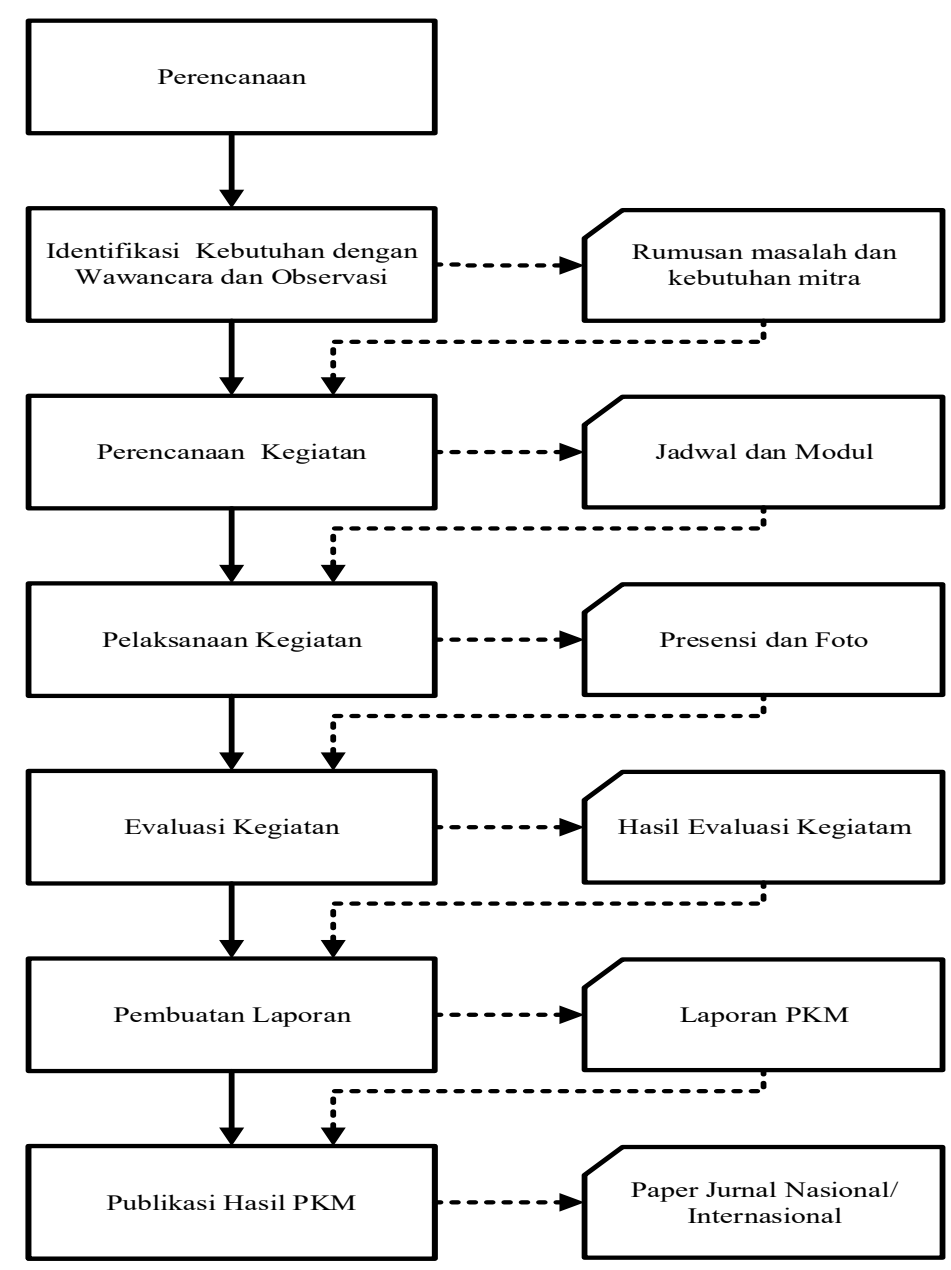

Gambar 1. Tahapan kegiatan PKM

Berdasarkan Gambar 1, pelaksanaan kegiatan pengabdian kepada masyarakat (abdimas) dimulai dengan tahap perencanaan yaitu berkomunikasi intensif dengan pihak PKBM Bhakti Asih dalam rangka melakukan identifikasi kebutuhan dan permasalahan mitra. Metode yang digunakan adalah metode wawancara secara daring dan observasi lapangan dengan tetap memperhatikan protokol kesehatan yang berlaku. Selanjutnya disusun perencanaan kegiatan dengan menyepakati jadwal kegiatan dan menyusun modul pelatihan. Sarana dan prasarana yang diperlukan dalam pelaksanaan kegiatan seperti akun Zoom, formulir presensi dan materi kegiatan juga dipersiapkan dengan baik. Selanjutnya, untuk mengevaluasi pelaksanaan kegiatan dilakukan penyebaran formulir evaluasi yang diisi oleh peserta pelatihan. Setelah kegiatan berlangsung, tim pelaksana abdimas menyusun laporan kegiatan, dan pembuatan draf publikasi kegiatan di jurnal nasional atau internasional.

Pelaksanaan kegiatan pengabdian kepada masyarakat dilakukan dalam bentuk pelatihan sehari dengan rincian sebagai berikut :

- Tanggal : 29 Juli 2020

- Waktu : 09:00 WIB - Selesai

- Media : Daring menggunakan aplikasi Zoom Cloud Meeting

- Peserta : guru dan siswa

Peserta yang mendaftar mengikuti pelatihan dan workshop ini berjumlah 21 orang yang 
terdiri dari guru, staf, dan siswa PKBM Bhakti Asih. Setelah kegiatan berakhir, dilakukan evaluasi dengan pengisian kuesioner secara daring melalui aplikasi Google Form. Hasil kuesioner diolah dan dianalisis sehingga menjadi masukan bagi penyelenggaraan kegiatan sejenis di masa mendatang.

\section{HASIL}

\section{Komunikasi dengan Zoom Cloud Meeting}

Zoom Cloud Meeting merupakan salah satu penyedia layanan konferensi video daring yang sangat populer sejak terjadinya pandemi Covid-19. Dengan aplikasi Zoom, dapat dilakukan panggilan video dan suara secara realtime dengan banyak pengguna sekaligus. Salah satu kelebihan aplikasi Zoom adalah perekaman percakapan yang dapat disimpan dan diputar di kemudian hari.

Sejak awal tahun 2020, jumlah pengguna aplikasi Zoom mengalami peningkatan yang sangat signifikan akibat merebaknya pandemi Covid-19. Pada kuartal I Tahun 2020, jumlah pendapatan Zoom mengalami kenaikan hingga 169\% dibanding kuartal yang sama di tahun sebelumnya [7]. Hal tersebut tentu seiring dengan peningkatan jumlah penggunanya. Pada bulan Mei 2020 diperkirakan jumlah pengguna aktif Zoom mencapai 173 juta pengguna atau mengalami peningkatan hingga seribu persen dibanding tahun sebelumnya.

Zoom menyediakan layanan secara gratis dan berbayar dengan beberapa perbedaan fitur dan kapasitas layanan. Aplikasi Zoom dapat diunduh secara gratis baik dalam bentuk aplikasi mobile (Android dan iOS) maupun aplikasi desktop di berbagai sistem operasi. Pengguna Zoom gratis memiliki keterbatasan dalam jumlah pengguna dan waktu konferensi. Jumlah peserta konferensi dibatasi hanya 100 orang peserta dengan waktu konferensi paling lama 40 menit. Sementara untuk layanan berbayar, pengguna dapat memilih beberapa alternatif paket biaya sesuai kebutuhan dan fitur yang diinginkan pengguna.

Beberapa fitur unggulan yang dimiliki Zoom adalah:

1) Penjadwalan pertemuan

Dengan fitur ini, memungkinkan pengguna mengatur jadwal pertemuan sebelum pertemuan berlangsung. Fitur ini bermanfaat bagi pengguna Zoom yang memiliki banyak agenda pertemuan.

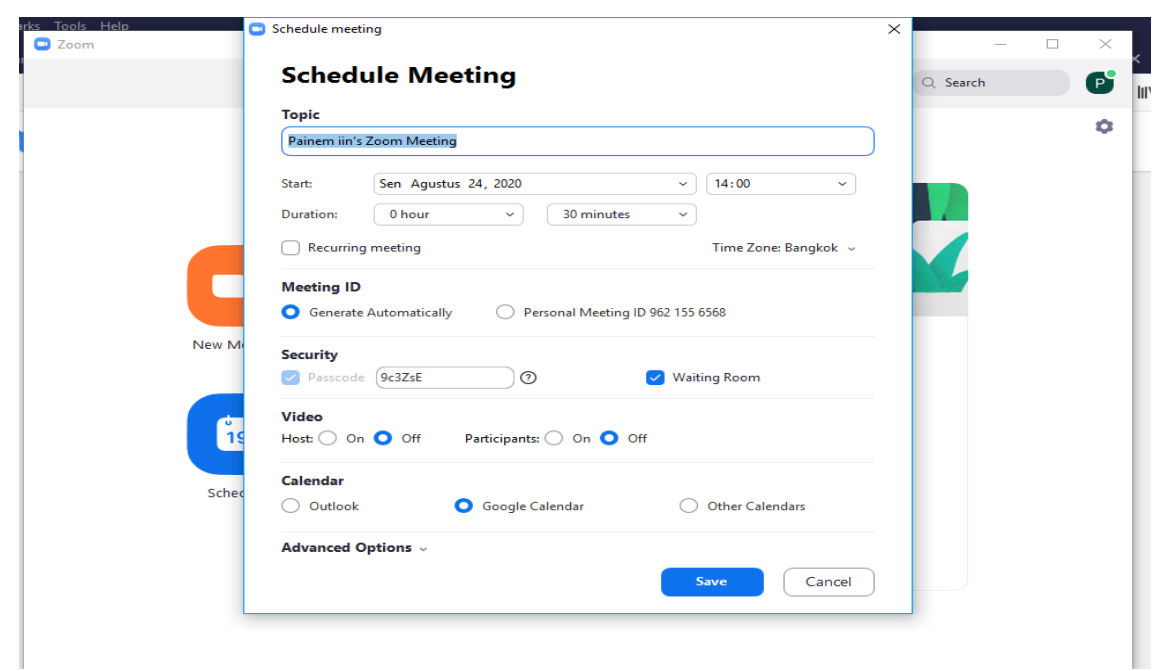

Gambar 2. Schedule a meeting 


\section{2) Penyelenggaran (host) pertemuan}

Dalam sebuah pertemuan keberadaan panitia penyelenggara atau pemimpin acara yang mengatur keberlangsungan acara sangatlah diperlukan. Pada aplikasi Zoom tersedia fitur serupa, yakni Host a Meeting dan juga Co-Host yang dapat membantu seorang host dalam mengatur jalannya pertemuan. Seorang host dapat mengatur hak akses peserta pertemuan antara lain apakah peserta dapat menyalakan video, menyalakan audio (suara), atau berbagi file dan melakukan presentasi.

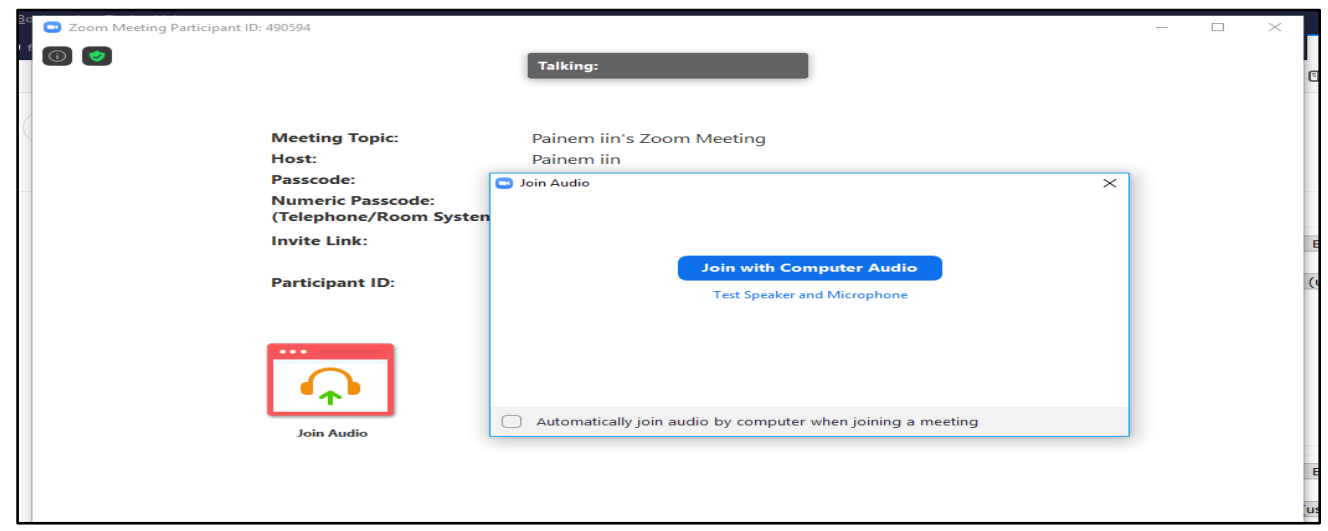

\section{Gambar 3. Host Meeting}

\section{3) Latar belakang virtual}

Saat melakukan pertemuan, peserta pelatihan dapat mengatur latar belakang yang dimunculkan di belakang video peserta. Zoom memfasilitasi penggunanya dengan fitur mengubah latar belakang (virtual background). Virtual background dapat diganti dengan berbagai pilihan gambar yang tersedia, ataupun menggunakan pilihan gambar yang dimiliki oleh peserta sendiri.
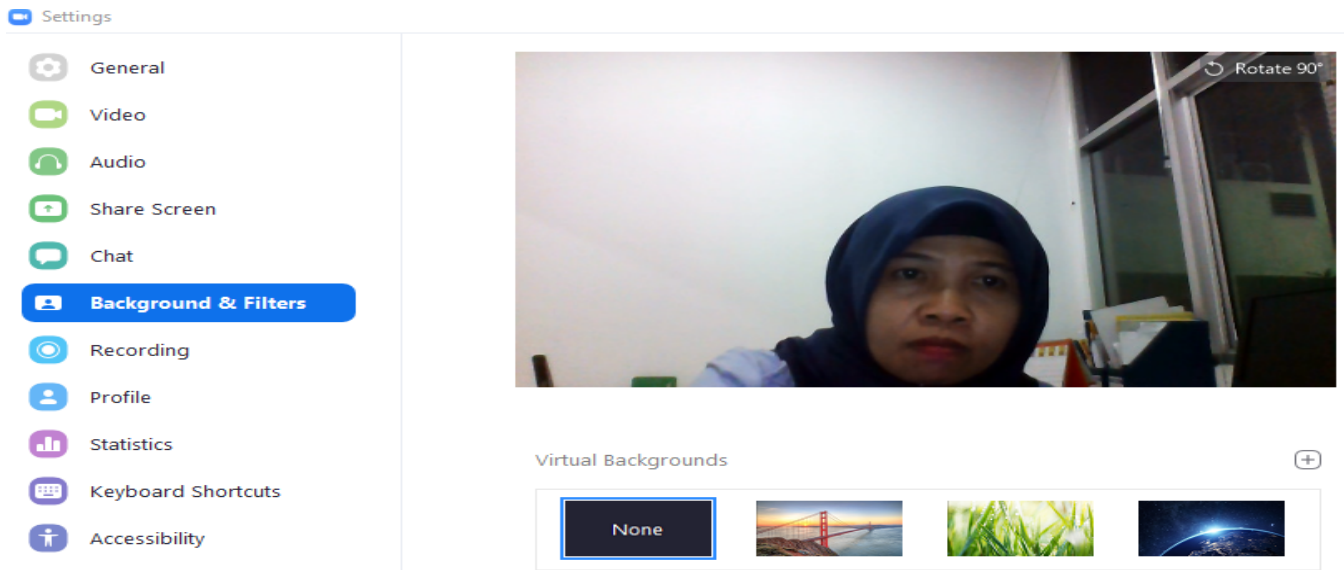

\section{Gambar 4. Virtual Background}

4) Filter wajah

Zoom juga memiliki fitur untuk menambahkan filter wajah. Peserta dapat menghaluskan 
atau mencerahkan warna kulit atau menambahkan filter seperti di beberapa aplikasi sosial media. Untuk menggunakan fitur ini, kita memerlukan Zoom versi 4.0 yang lebih baru untuk macOS, Windows, iOS atau Android. Cara mengaktifkannya, buka profile image, klik settings, lalu kik Video Touch up my appearance. Jika belum berhasil juga kita bisa mengaksesnya melalui Video Settings lalu klik Touch up my appearance.

\section{5) Perekaman Video Pertemuan}

Salah satu kelebihan aplikasi Zoom adalah mampu merekam dan menyimpan video selama pertemuan berlangsung. Hasil rekaman dapat disimpan secara lokal di komputer penyelenggara, atau diunggah ke layanan penyimpanan file daring seperti Google Drive, Dropbox, dan sebagainya. Selain video, perekaman juga secara otomatis akan menyimpan transkrip pembicaraan pada fitur chat yang dilakukan oleh peserta pertemuan.

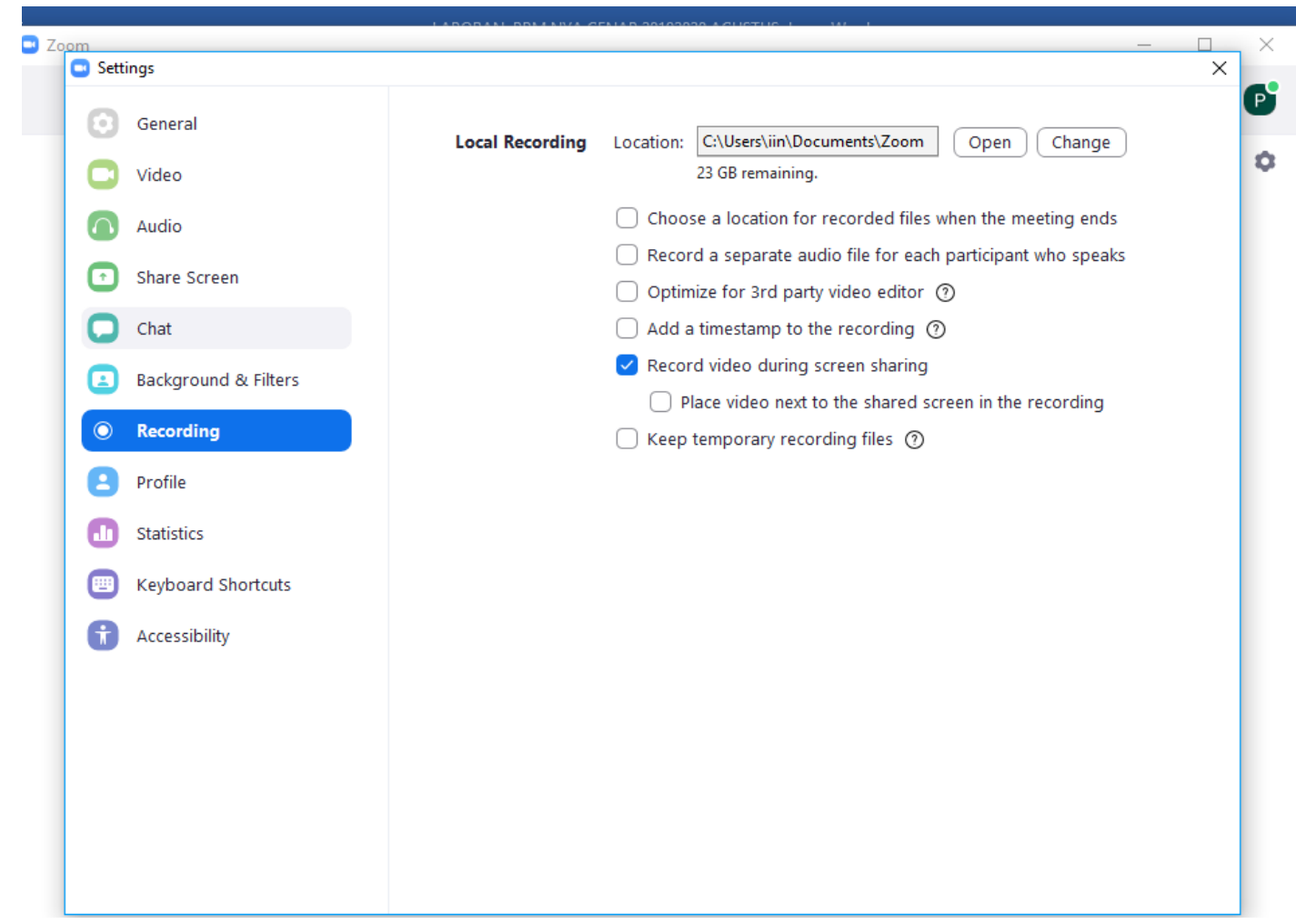

Gambar 5. Rekam dan simpan video

\section{Evaluasi Pelaksanaan Kegiatan}

Evaluasi pelaksanaan kegiatan dilakukan terhadap dua hal, yaitu evaluasi pelaksanaan kegiatan secara umum dan evaluasi narasumber pelatihan. Evaluasi melibatkan responden dari seluruh peserta pelatihan yang mengikuti kegiatan pelatihan. Berdasarkan hasil evaluasi penyelenggaraan pelatihan yang telah dilakukan dapat disimpulkan bahwa sebagian besar peserta merasa puas atas terselenggaranya pelatihan. Gambar 6 menunjukkan hasil evaluasi penyelenggaraan pelatihan yang diperoleh menggunakan metode kuesioner yang diisi oleh seluruh peserta. Evaluasi pelaksanaan kegiatan pelatihan menilai 7 (tujuh) aspek yaitu koneksi internet, kebermanfaatan aplikasi zoom dalam mendukung komunikasi, manfaat aplikasi zoom dalam pekerjaan, kesiapan sarana dan prasarana pelatihan, suasana pelatihan, ketepatan waktu penyelenggaraan pelatihan, dan kualitas materi pelatihan. 


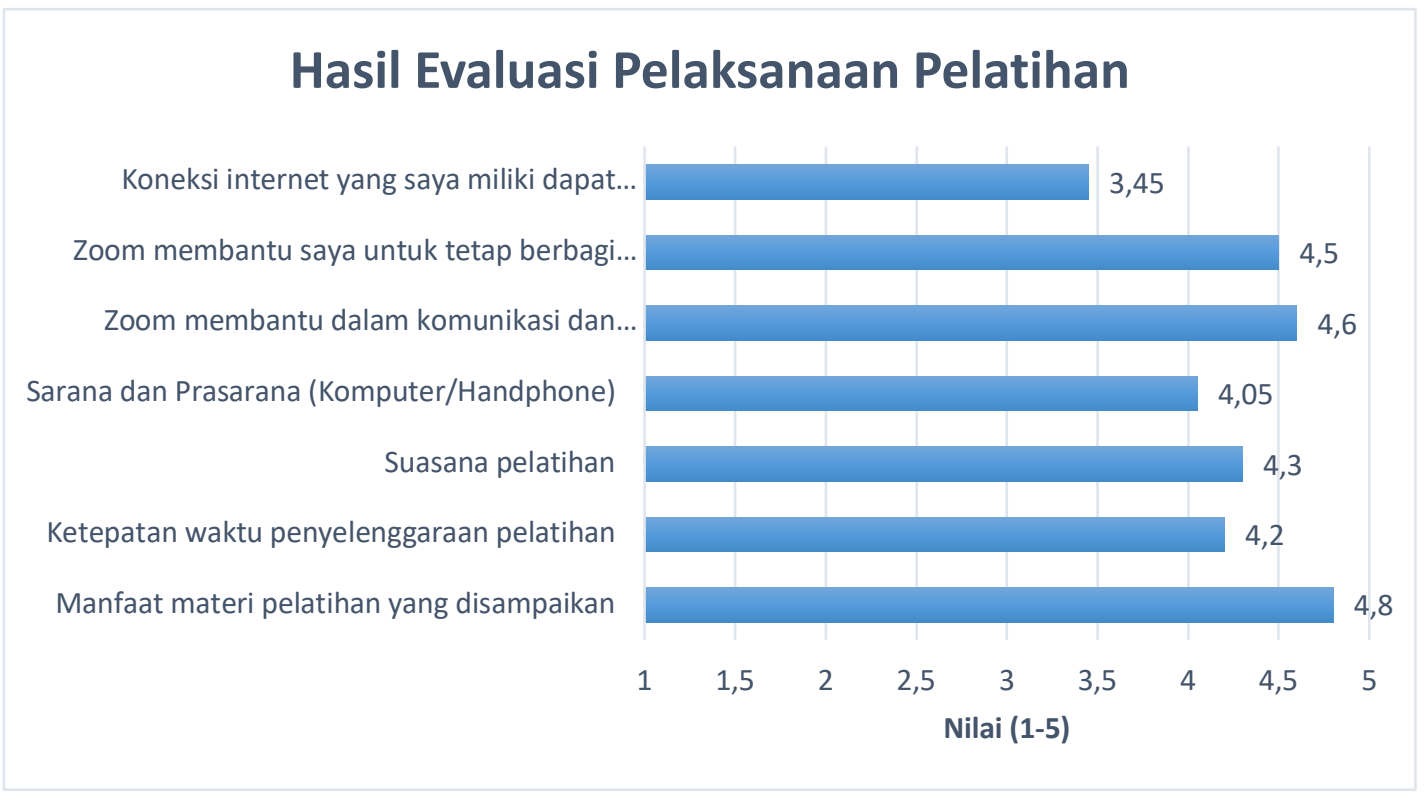

\section{Gambar 6. Hasil Evaluasi Pelaksanaan Kegiatan}

Hal-hal yang masih perlu diperbaiki dari pelaksanaan pelatihan adalah koneksi internet yang dimiliki peserta dalam menjalankan zoom dan sarana dan prasana (komputer/handphone) peserta pelatihan. Untuk koneksi internet yang dimiliki oleh peserta tergantung dari lokasi, kuota yang dimiliki peserta serta ketersediaan jaringan selular yang dimiliki. Sedangkan untuk sarana dan prasana seperti laptop, komputer ataupun handphone keterbatasan sarana dan prasarana yang dimiliki peserta yang berbeda-beda. Secara umum penilaian pesertaa terhadap pelaksanaan pelatihan dalam kategori baik dengan nilai 4,27 dalam rentang penilaian 1 hingga 5.

Berdasarkan hasil evaluasi narasumber terlihat bahwa peserta cukup puas dengan kualifikasi dan materi yang disampaikan oleh narasumber. Hal tersebut terlihat pada hasil evaluasi peserta pelatihan terhadap narasumber yang disajikan pada Gambar 7. Secara umum seluruh peserta mempunyai anggapan bahwa narasumber telah menguasai materi dengan sangat baik. Terlihat dari hasil evaluasi dalam hal pengusaan materi diperoleh nilai rata-rata 4,70 dalam rentang nilai 1 hingga 5. Secara umum penilaian peserta terhadap evaluasi narasumber dalam kategori baik dengan nilai 4,42 dalam rentang 1 hingga 5 .

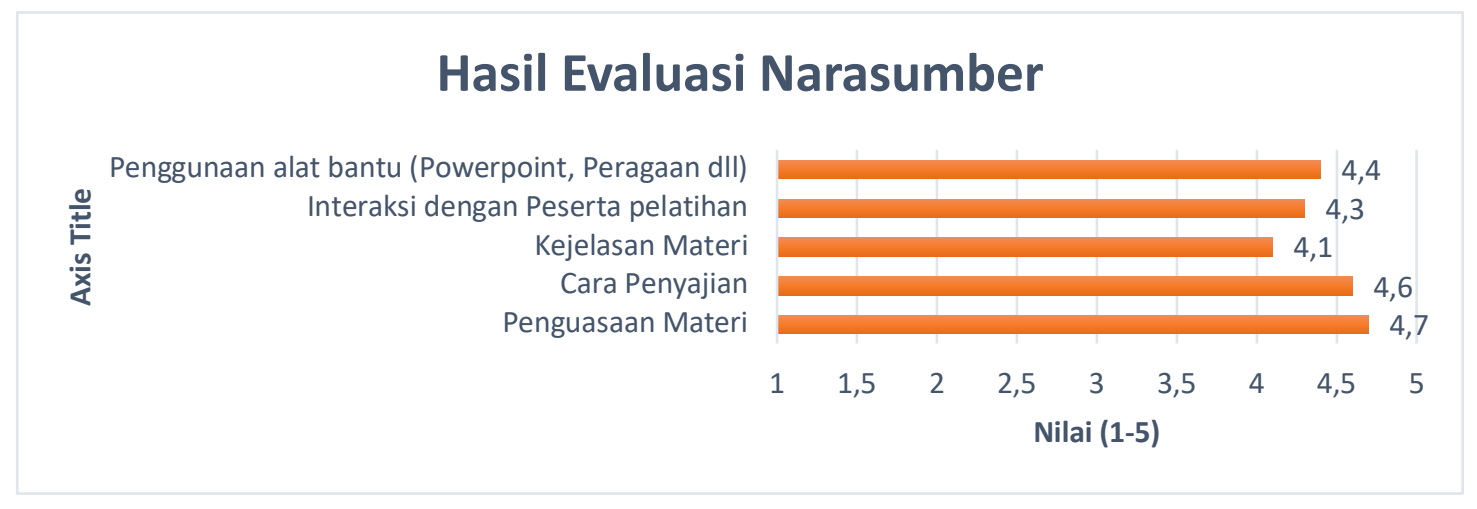

Gambar 7. Hasil Evaluasi Narasumber Pelatihan 


\section{Dokumentasi Kegiatan}

Kegiatan Pengabdian Kepada Masyarakat diikuti 21 peserta siswa dan guru PKBM Bhakti Asih. Pada Gambar 8 adalah foto pelaksanaan pengabdian kepada masyarakat yang dilaksanakan dengan menggunakan zoom meeting
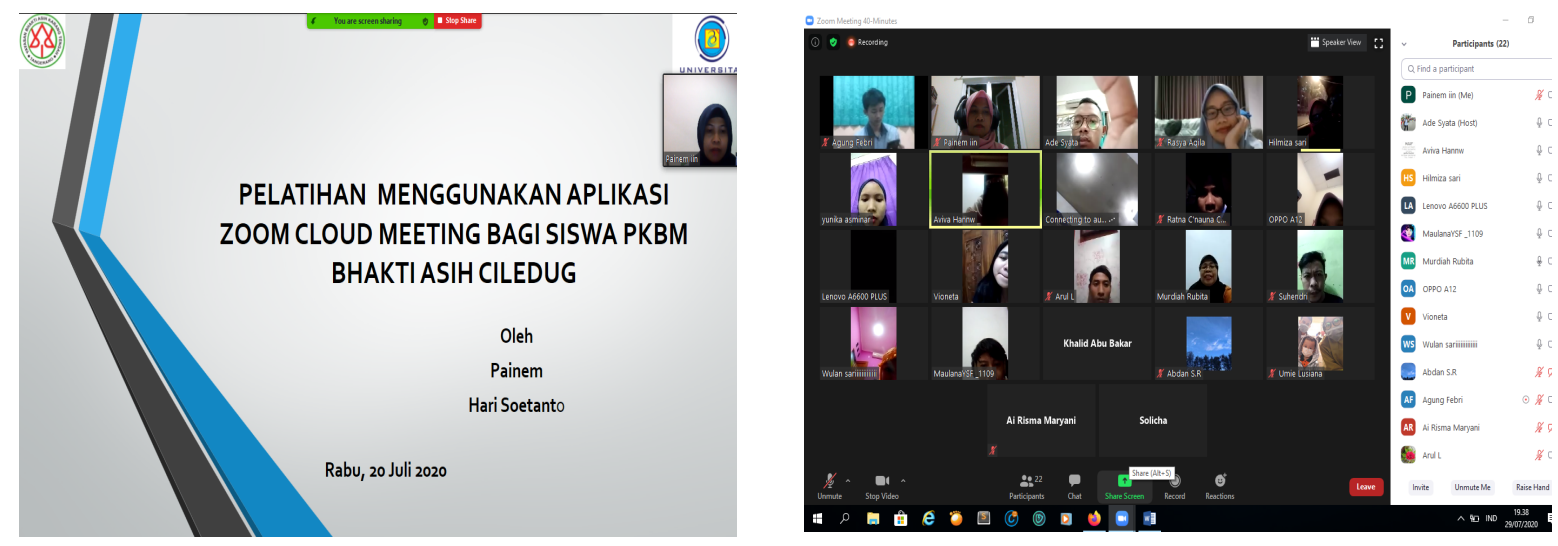

Gambar 8. Dokumentasi Pelaksanaan kegiatan PKM

\section{KESIMPULAN}

Berdasarkan pelaksanaan kegiatan dan hasil evaluasi kegiatan pengabdian kepada masyarakat (abdimas) di PKBM Bhakti Asih dapat disimpulkan bahwa:

a. Kegiatan abdimas ini membantu PKBM Bhakti Asih untuk meningkatkan kemampuan guru dan siswa dalam penggunaan Aplikasi Zoom sebagai salah satu sarana komunikasi dan koordinasi massal.

b. Pelaksanaan kegiatan pelatihan berjalan dengan lancar dan dihadiri oleh 21 peserta pelatihan yang terdiri dari siswa dan guru PKBM Bhakti Asih.

c. Peserta yang mengikuti pelatihan beragam usianya, namun seluruh peserta antusias dalam mengikuti pelatihan ini sampai selesai.

d. Berdasarkan hasil penilaian peserta terhadap pelaksanaan pelatihan dalam kategori baik dengan nilai 4,27 dalam rentang 1-5.

e. Berdasarkan hasil penilaian peserta terhadap evaluasi narasumber dalam kategori baik dengan nilai 4,42 dalam rentang 1-5.

Berdasarkan hasil evaluasi terhadap penyelenggaraan kegiatan, kualitas kegiatan perlu ditingkatkan penyelenggaraannya di masa mendatang. Beberapa saran untuk pelaksanaan kegiatan pengabdian kepada masyarakat (abdimas) di masa mendatang antara lain sarana dan prasarana pelatihan seperti koneksi internet dan perangkat yang digunakan perlu dipersiapkan dengan lebih matang demi kelancaran proses pelatihan

\section{DAFTAR PUSTAKA}

[1] Painem, H. Soetanto, and G. Triyono, "Peningkatan Kualitas Sumber Daya Manusia Melalui Pelatihan Microsoft Word Pada Pusat Kegiatan Belajar Masyarakat ( Pkbm ) Bhakti Asih," Pros. Semin. Nas. Pengabdi. Kpd. Masy., pp. 65-69, 2019. 
[2] H. N. Hidayatullah, "Implementasi Program Pelatihan Komputer bagi warga belajar paket C di PKBM Bina Terampil Mandiri Kertawangi," J. comm-edu, vol. 1 No. 1, pp. 59-68, 2019.

[3] N. Kurniasari, "Pelatihan Manajemen Acara bagi Warga Belajar Pusat Kegiatan Belajar Masyarakat Ristek Nusantara Jaya Jakarta sebagai bentuk Pengabdian Kepada Masyarakat," Pros. PKM-CSR, vol. 1, pp. 1142-1152, 2018.

[4] Hendy, A. Rahmawati, and Sujarwo, "Program Kejar Paket ++ Di Pusat Kegiatan Belajar Masyarakat (Pkbm) Di Kelurahan Gayam Dan Bandar Lor Kecamatan Mojoroto Kota Kediri," J. Pengabdi. Masy. Univ. Merdeka Malang, vol. 3, no. 1, pp. 1-3, 2019.

[5] V. Octaviani, S. Narti, and S. Nurwita, "Peningkatan Sumber Daya Masyarakat Desa dalam Binaan Pusat Kegiatan Belajar Masyarakat (PKBM)," J. Pengabdi. Pada Masy., vol. 3, no. 2, pp. 117-124, 2018.

[6] L. D. Setia and T. Lestariningsih, "Pelatihan Karya Tulis Bagi Guru Non Formal (PKBM Kelurahan Kertosari Ponorogo)," DIKEMAS (Jurnal Pengabdi. Kpd. Masyarakat), vol. 2, no. 1, pp. 1-6, 2018.

[7] C. M. Annur, "Pengguna Video Melonjak Selama Pandemi, Pendapatan Zoom Naik 169\%," Katadata, 2020. [Online]. Available: https://katadata.co.id/ekarina/digital/5ed8a03baa91b/pengguna-video-melonjak-selamapandemi-pendapatan-zoom-naik-169. 